\title{
Functionalism Theory Applied in C-E Translation of Chinese Food Culture Text
}

\author{
Siwei Yue \\ Foreign Languages Department, Guangdong University of Education, Guangzhou, China
}

\begin{abstract}
According to functionalism theory, the translation is a reproduction process of source text in target language, observing the target culture. The target language features in terms of contents, sentence structure and lexis should be considered as criteria to adapt the source text before translating. The source text elements that do not fit in target culture should be revised or even neglected in translating so as to transfer the flavor of source text while not violating target culture.
\end{abstract}

Index Terms - functionalism, C-E translation, food culture, text

\section{INTRODUCTION}

Recent years witnesses the prosperity of China's economy. At the same time, China's economic and cultural communication with other nations is accordingly on the increase. More and more foreigners become interested in the Chinese culture. As an indispensable part of the Chinese culture, Chinese food has gained its fame worldwide. With a great growth of the number of people abroad fascinated by Chinese food, an accurate English translation of the Chinese food culture text becomes a must for it facilitates the entry of the Chinese food products into the international market and the efforts to help boost China's tourism that is well beginning to attract custom from overseas. To know more about the Chinese food, foreigners are not only expected to appreciate the flavor of each dish but also to understand the history and the food culture behind it.

Nowadays, there are studies of the translation of Chinese food by many scholars from different perspectives, but it seems that most of them simply focus on how to translate the names of dishes, which ignores the importance of the study on how to deliver the essence of Chinese cuisine - the Chinese food culture. This research is devoted to the C-E translation strategy and evaluation of Chinese food culture text from a functionalism perspective, hopefully bridging the Chinese food culture and western perceptions by providing accurate translations.

\section{Functionalism Theory and C-E Translation of Chinese Food Culture TeXt}

\section{A. Functionalism Theory Applied in Translation Strategy}

The functionalism theory believes that a proper translation is an endeavor to maintain the flavor of source text during the language transfer while not violating the target language system. In other words, a good translation should deliver the source text meaning as well as the source-culture imbedded in the language and the audience of the target language and target-culture feel the same way as the source text audience about the text. But it seems impossible for audiences from different culture with different language system to share the same information and affection of a text if the translation is conducted simply in a coding way where faithfulness principle in translation is deduced into word-to-word translation. Therefore, the functionalism defines that the translator is not the sender of the source text message but a text-producer in the target culture who adopts somebody else's intention in order to produce a communicative instrument for the target culture, or a target-culture document of a source-culture communication (Nord, 2006). The translator recreates the text in target language by keeping some source-text information or linguistic elements invariant and adapting the rest to the receivers' background knowledge, expectations and communicative needs or to such factors as medium-restrictions and deixis requirements (Nord, 2001). Consequently, from the functionalism perspective, the translation strategy of Chinese text into English is not mainly restricted to source text information but also needs considering how to bridge the western culture and Chinese culture conveyed in the text.

\section{B. The Functionalism Impact on C-E Translation of Chinese Food Culture Text}

As a general rule in functionalism, texts are not produced just in order to be translated but to fulfill certain communicative purposes for a specified source language audience (Nord, 2006).Chinese food, as one world-known Chinese culture factor, is appealing to westerners both because of its taste and the exotic Chinese food culture. The C-E translation of Chinese food culture text becomes most demanding for the communicative purpose of translation is to promote Chinese food culture. The reception of a text depends on the individual expectations of the receivers, which are determined by the situation in which they receive the text as well as by their social background, their world knowledge and their communicative needs (Nord, 2006). Thus, the translation strategy of Chinese food culture text focuses on the reproduction of an English text introducing the Chinese food culture in a manner adapted to the westerner's 
expectations of food culture texts, their knowledge of the western food introduction format and their communicative needs. To achieve this goal, the translation starts with the processing of source text and target profiles. Nord (2001) states that "the comparison between the source-text and target profiles shows very clearly what source-text information or linguistic elements can be kept invariant and what has to be adjusted to the requirements of the translation purpose". The following research will make a contrast between the source-text (Chinese food culture text) under the Chinese food culture and the target profiles (western food culture text) under western food culture, by which the processing of source text and target profiles can be accurately done during translating.

\section{The Contrast Between Chinese And Western Food Culture TeXT}

By analyzing the data from a variety of Chinese food culture text and Western food culture text, the research comes up with a contrastive summary to characteristics of each food culture text in terms of content composition, sentence structure and lexis function. The data quoted below chiefly derived from three samples on each side. (The samples are listed in appendix)

\section{A. The Contrast in the Composition of Content}

The Chinese food culture text usually covers the school of the cuisine, the ranking of the dish, the history or stories about this dish, the taste, the special serving manner( if provided), the improvement of the technique preparing this dish and the naming of this dish. Among them, the school of cuisine, the ranking, taste, cooking technique and serving manner differ from the rest in the nature of content. The former is closely related to the physical feature of the food while the latter attaches importance to the legendary anecdotes of the food. TABLE I. shows the rate of the numbers of the physical feature and anecdote sentence in the three samples.

TABLE I.

RATE OF PHYSICAL FEATURE CONTENT AND ANECDOTE CONTENT IN CHINESE TEXT (UNIT: SENTENCE)

\begin{tabular}{|l|l|l|l|l|l|l|}
\hline \multirow{2}{*}{ Sample } & Physical feature & \multicolumn{2}{|l|}{ Anecdote } & \multirow{2}{*}{ Rate } \\
\cline { 2 - 6 } & Taste & School of cuisine & History & Improvement & Naming & \\
\hline$(1)$ & 1 & 1 & 4 & 1 & 1 & $2: 6$ \\
\hline$(2)$ & 1 & 1 & 2 & 3 & 1 & $2: 6$ \\
\hline$(3)$ & 0 & 1 & 3 & 1 & 1 & $1: 5$ \\
\hline
\end{tabular}

Obviously, according to the figure, the anecdotes prevail in the Chinese food culture text over the physical features. The historical stories overweigh the introduction to the school of cuisine, taste and cooking technique.

As to the content of the western food culture text, it usually contains four parts: region of origin of this cuisine, ingredients, naming of this cuisine, the history or stories about this dish. To facilitate the contrast to Chinese food culture text, the mentioned four parts of the content can also be categorized into two types: the physical feature of food and the anecdotes. The analysis in TABLE II concludes that the physical features spend more sentences than anecdotes in the western food culture texts. It reaches more than half which is sharply increasing from the Chinese food culture text rate. The anecdotes in the western food culture texts are still attached to the introduction of physical factors of the food.

TABLE II. RATE OF PHYSICAL FEATURE CONTENT AND ANECDOTE FEATURE CONTENT IN WESTERN TEXT (UNIT: SENTENCE)

\begin{tabular}{|c|c|c|c|c|c|}
\hline \multirow{2}{*}{ Sample } & \multicolumn{2}{|l|}{ Physical feature } & \multicolumn{2}{|c|}{ Anecdote } & \multirow{2}{*}{ Rate } \\
\hline & School of cuisine & Ingredient & History & Naming & \\
\hline (4) & 2 & 2 & 3 & 2 & $4: 5$ \\
\hline (5) & 1 & 2 & 0 & 1 & $3: 1$ \\
\hline (6) & 2 & 3 & 3 & 1 & $5: 4$ \\
\hline
\end{tabular}

To sum up, in the composition of content, the Chinese and English food culture texts may be observed to cover the region of origin of the cuisine, cooking, naming of this cuisine, special features. As compared with the Western food culture text, the Chinese food culture text cares more about the detailed history, such as the time of the invention of a dish, the related historical figures and events, the improvement of the dish which leads to old stories. On the contrary, the English food introduction gives priority to content such as the ingredients, the skills by which to prepare a dish. Therefore, to compare the Chinese and western food culture text in terms of the composition of content, a tremendous difference is that the Chinese food culture text attaches much importance to the anecdotes of the food, such as the time of the invention of a dish, the related historical figures and events, the improvement of the dish which leads to old stories, all of which may be considered cultural background of the cuisine but less relevant to the direct information about the cuisine itself. But the Western food culture text talks much more to the point for it puts a lot of weight on introducing the ingredients, taste, the skills by which to prepare a dish and how to cook and eat the food which are more directly related to the food itself.

\section{B. The Contrast in Sentence Structure}

The sentence structure of the Chinese food culture text is characterized by the use of two sentence types. The first 
type (type 1) is sentences where some of the clauses possess different subjects in the framework of "Subject+V1+V2 ... Subject1+V3+V4..." and the second type (type 2) includes sentences where the clauses are put together in the framework of "Subject + V1+V2...", sharing the same subject. This phenomenon is reflected in TABLE III.

TABLE III.

THE DISTRIBUTION OF TWO SENTENCE TYPES IN CHINESE TEXT

\begin{tabular}{|l|l|l|}
\hline Sample & Type 1 & Type 2 \\
\hline$(1)$ & d. e. & a. f. \\
\hline$(2)$ & a.d. & a.c.f. \\
\hline$(3)$ & d. & a.c. \\
\hline
\end{tabular}

Similarly, by analyzing the sentence structure of western food culture texts, the research pinpoints two features about western food culture texts' sentence structure: massive use of sentences in passive voice, the employment of complex sentences or simple sentences with modifiers and inserted elements. The application of these two sentence types are clearly recorded in TABLE IV.

TABLE IV.

THE DISTRIBUTION OF TWO SENTENCE TYPES IN WESTERN TEXT

\begin{tabular}{|l|l|l|}
\hline Sample & Passive voice & Complex sentence \\
\hline$(4)$ & a.c. g. i. j.n. & g. h. i.k \\
\hline$(5)$ & a.b.e & c.e \\
\hline$(6)$ & a.e.g & a.b.c.e.f.g \\
\hline
\end{tabular}

To make a contrast in sentence structure, the Chinese food culture text differs a lot from their western counterparts. Firstly, the sentence structure of the Chinese texts is changeable and variegated in nature because as can be observed the subject of the sentence shifts from time to time. The clauses of a Chinese sentence possess different subjects which can be described in the framework "Subject+V1+V2...Subject1+V4+V5..." not clearly indicating in which way they are related to one another, which reinforces a scholarly claim that Chinese is a language of parataxis where language elements are put together without using many connective devices (Liu, 2001). In order to convey complicated meanings and information, the Western food culture text, however, bring in complex sentences and simple sentences filled with inserted elements and post-modifiers so that layers upon layers of meanings can be readily identified, with the subject of the sentence stretching on consistently, presupposing the subjects of the clauses in a way grammatically and texturally possible. Secondly, whereas in Chinese sentences clauses may often be observed to share one subject, appearing in the "Subject+V1+V2..." pattern, which conforms to the fact that lack of the subject of a sentence is a constant thing in Chinese (Hu, 1994), the opposite may be said true of the case with English sentences where almost every clause, to say nothing of a sentence, starts with the subject as a point of departure.

\section{The Contrast in the Function of Lexis}

The diction used in the Chinese food culture text can be roughly categorized into three types according to function. The first type, known as referential lexis, covers the words for providing essential information, that is, for informing the reader of the objects and phenomena in the real world. The second type, namely cohesive lexis, contains the words for bringing about coherence and transition of the text by functioning as cohesive devices. The third type, called beautifying lexis includes the words for enhancing the atmosphere, beautifying the language, invigorating the objects or phenomena or/and expressing the text producer's attitude toward them. To simplify the calculation in lexis rate, the first type is also defined as informative lexis while the second and third type is also combined to be referred as functional words which mainly help to smooth or beautify the text but not aims to provide any essential information of the food culture.

In TABLE V., the typical lexis in the three Chinese food culture text samples are put in the three types. 
TABLE V.

THE DISTRIBUTION OF LEXIS OF DIFFERENT FUNCTION IN CHINESE TEXT

\begin{tabular}{|c|c|c|c|}
\hline Sample & Referential function & Cohesive function & Beautifying function \\
\hline (1) & $\begin{array}{l}\text { 北京烤鸭(Beijing Roast Duck)、中国(China)、宋(Song } \\
\text { Dynasty)、元(Yuan Dynasty)、三百年(300-year-old)、采鸭 } \\
\text { (grilled dusk)、烧鸭(roast duck)、朱元璋(Zhu Yuanzhang)、 } \\
\text { 南京(Nanjing)、炭火(coal) }\end{array}$ & $\begin{array}{l}\text { 进一步(further)、单单 } \\
\text { (only)、已有(already)、 } \\
\text { 更(even)、随之(along) }\end{array}$ & $\begin{array}{l}\text { 首屈一指(be second to none among)、佳 } \\
\text { 有(exquisite)、醞香肥美、肥而不戚 } \\
\text { (fleshy, delicious, but not greasy) }\end{array}$ \\
\hline (2) & $\begin{array}{l}\text { 涮羊肉(Instantly Boiled Mutton in a Mongolian Fire Pot)、羊 } \\
\text { 肉火锅(Mutton in Fire Pot)、北京(Beijing)、元代(Yuan } \\
\text { Dynasty)、忽必烈(Kublai Khan)、宫廷(the Palace)、千舅宴 } \\
\text { (“One Thousand Elderly Men Feast”)、民间(every } \\
\text { household)、十七世纪中叶(the middle of } 17^{\text {th }} \text { century) }\end{array}$ & $\begin{array}{l}\text { 逐渐(gradually)、便 } \\
\text { (consequently)、从此 } \\
\text { (ever since) }\end{array}$ & $\begin{array}{l}\text { 颇具(so boast for)、逼近(impend over)、 } \\
\text { 津津有味((racily)、喜开颜笑(be } \\
\text { excited)、大设(luxuriously held } \\
\text { banquet)、大震(well-known)、食趣(the } \\
\text { fun of eating)、热淡鲜美(delicious and } \\
\text { fresh) }\end{array}$ \\
\hline (3) & $\begin{array}{l}\text { 安徽(Anhui Province)、凤阳(Fengyang city)、明朝(Ming } \\
\text { Dynasty)、朱元璋(Emperor Zhu Yuanzhang)、酿豆腐 } \\
\text { (Preserved Beencurd)、洪武豆腐(Emperor Hongwu's } \\
\text { beencurd)、饭馆(restaurant)、厨师(chef)、老板(the restaurant } \\
\text { owner) }\end{array}$ & $\begin{array}{l}\text { 就(then)、后(ever } \\
\text { since)、便 } \\
\text { (consequently)、已有 } \\
\text { (there have been)、经 } \\
\text { 常(occasionally)、时常 } \\
\text { (sometimes) }\end{array}$ & $\begin{array}{l}\text { 系(namely)、驰名于世(world-famous)、 } \\
\text { 名菜(exquisite dish)、风味(flavor) }\end{array}$ \\
\hline
\end{tabular}

In TABLE VI., the three types of lexis are calculated in two groups: informative lexis and functional lexis.

TABLE VI.

RATE OF INFORMATIVE LEXIS AND FUNCTIONAL LEXIS IN CHINESE TEXT (UNIT: WORD)

\begin{tabular}{|l|l|l|l|l|}
\hline \multirow{2}{*}{ Sample } & Informative lexis & Functional lexis & \multirow{2}{*}{ Rate } \\
\cline { 2 - 5 } & Referential lexis & Cohesive lexis & Beautifying lexis & $10: 9$ \\
\hline$(1)$ & 10 & 5 & 4 & $9: 11$ \\
\hline$(2)$ & 9 & 3 & 8 & $9: 10$ \\
\hline$(3)$ & 9 & 7 & 3 & \\
\hline
\end{tabular}

Following the same categorization of lexis with the Chinese food culture text, the lexis used in the western food culture text is recorded in TABLE VII.and TABLE VIII which applies the format of TABLE V and TABLE VI.

TABLE VII

THE DISTRIBUTION OF LEXIS OF DIFFERENT FUNCTION IN WESTERN TEXT

\begin{tabular}{|c|c|c|c|}
\hline Sample & Referential function & Cohesive function & Beautifying function \\
\hline (4) & $\begin{array}{l}\text { Paella,Spain,Valencia,eastern Spain,rice...chicken, } \\
\text { pork, shellfish, fish,eel,squid,beans,peas,pepper } \\
\text { artichokes, }\end{array}$ & it, however, or, and, but, & $\begin{array}{l}\text { internationally-known, as } \\
\text { many as, essential, wonderful, } \\
\text { romantic }\end{array}$ \\
\hline (5) & $\begin{array}{l}\text { Mexican; avocado; chilies; lime; lemon } \\
\text { juice;tomatoes;spring;onion; } \\
\text { cilantro(coriander) ;“" guacamole” ;“agucate”; } \\
\text { "mole”; cities; Monterrey; garnish; dish; red; } \\
\text { white; green stripes; flag. }\end{array}$ & so; and; or; so that & none \\
\hline (6) & $\begin{array}{l}\text { Porto people, tripe recipe, Caen's, Lyonnaises, or } \\
\text { the callos à Madrilenã, Prince Henry, caravel, } \\
\text { Ceuta, wooden barrel, vessel, black pepper, } \\
\text { sausage, fat chicken }\end{array}$ & $\begin{array}{l}\text { Although, them, then, later } \\
\text { on, not only but also, and, or }\end{array}$ & none \\
\hline
\end{tabular}

TABLE VIII.

RATE OF INFORMATIVE LEXIS AND FUNCTIONAL LEXIS IN WESTERN TEXT (UNIT: WORD)

\begin{tabular}{|l|l|l|l|l|}
\hline \multirow{2}{*}{ Sample } & Informative lexis & Functional lexis & \multicolumn{2}{l|}{ Rate } \\
\cline { 2 - 5 } & Referential lexis & Cohesive lexis & Beautifying lexis \\
\hline$(4)$ & 16 & 5 & 5 & $16: 10$ \\
\hline$(5)$ & 22 & 4 & 0 & $22: 4$ \\
\hline$(6)$ & 12 & 7 & 0 & $12: 7$ \\
\hline
\end{tabular}

Concerning the lexis, in both the Chinese and Western food culture text, the words used can be categorized into three types: words for the communication of information, words for bringing about the coherence and consistence of the text and words for enhancing the atmosphere, beautifying the language or/and expressing the text producer's attitude. But the different proportion of each type used in the Chinese and Western food culture text shows that the Chinese food culture text attaches much greater importance to the functional words for beautifying the language, enhancing the atmosphere than to the informative words, while the Western food culture text takes information words over the other types.

\section{The Problems in C-E Translation of Chinese Food Culture TeXt}

In the preceding studies, we have presented a more or less detailed study of the content, sentence structure and lexis factors in the Chinese and western food culture text and explored respectively the characteristics of the Chinese and the 
western food culture text from the lexical, structural and cultural perspectives. It is obvious that the Chinese food culture text differs greatly from the western food culture text in content, sentence and lexis which are closely related to the different cultural backgrounds. As to translating the Chinese food culture text into English, it is insufficient to start from the source-language elements and transfer it sentence by sentence, phrase by phrase, or word by word. In the functionalism translation theory, the translation starts on the pragmatic level by analyzing the target text skopos, that is, by deciding on the intended function of the translation. The second step is the analysis of the source text. A distinction is then made between those text elements of the source text that will have to be preserved and the ones that must be adapted to the target addressee's background knowledge, expectations and communicative needs. Therefore, to judge the English translation of the Chinese food culture text, the author should examine if the target text successfully adapts the text elements of source text to the target addressee's cultural expectations, thinking patterns and language, if the target text conveys the essence of the source text as well as fulfill the translation skopos. Put it simple, in English translation of the Chinese food culture text, the forming of target text should confirm to the characteristics of English food culture text and contents of original Chinese texts should be adapted according to the translation functions when put in the target text. The neglect of these factors results in many translation problems occurring in the English translation of Chinese food culture text. The case study below will showcase the specific malpractice in translation and hopefully lead to working out some translation strategies applicable to the translation of such texts.

\section{A. The Case Study on Translation Problems}

One Chinese food culture text - Yifu Fried Noodle is provided originally in Chinese below accompanied with a trial on its English translation.

清人伊秉绶任惠州知府, 为官清廉, 从不趋炎附势, 当地乡绅都惧怕他(1)。一次伊知府过生日, 众乡绅都知 道知府喜食面条, 于是不约而同送上的寿礼都是面条(2)。这下伊知府为难了, 看着堆积如山的面条不知如何是 好(3)。忽然灵机一动, 决定将寿筵都改为吃面条(4)。于是吩咐厨师将面条煮熟后, 分给大家吃(5)。由于决定的 突然, 厨师手忙脚乱, 误将面条投入烧热的大油锅中, 于是将错就错, 将全部面条炸过之后, 连者带炒, 送上 餐桌(6)。大家吃过后都说“好吃”(7)。知府非常高兴，将剩下炸过的面条为每条乡绅打包回家(8)。此菜流入了民 间，形成了现今的“干烧伊府面”(9)。

Yin Bingshou, of the Manchurian ethnic minority, served as governor of Huizhou(1). He was honest and upright, and never curried favor with the rich and powerful(2). Local gentry were afraid of him(3). On his birthday, wealthy people gave him an enormous amount of noodles as a birthday gift since they knew he loved noodles(4). The governor then and there decided to serve noodles to the well-wishers(5). Disrupted from their routine birthday preparation, the cooks mistakenly put the noodles into pots filled with oil for deep-frying, instead of putting them in pots with water(6). The guests admired the fried noodles for being "tasty"(7). Delighted, the magistrate asked the guests to take home any fried noodles they could not finish(8). On this basis, developed the recipe for fried noodles, or so it is said(9).

- Chinese Cuisine Recipes and Their Stories pp35

This is a typical C-E translation of Chinese food culture text the author randomly picked from "Chinese Cuisine Recipes and Their Stories" which is a bilingual book designed for oversea tourists and gourmets. This translation could be reviewed as follows.

In order to select the translation-relevant elements from the source text above, the differences between the source text and its intended target text should be listed out. This source text is a Chinese introduction of the dish 干烧伊府面 (fried noodles), covering the related historical figure-伊秉绶 (Yi Bingshou, governor of Huizhou) and the story about the dish. The target text is directed at the English speakers who are interested in the Chinese food. According to what may often be observed in the English food culture texts, the focus is not on historical figures and stories but on such content as the cooking procedure, taste, ingredients which provide the tangible elements about this dish. Therefore, the target text receiver expects to acquire more information about how to cook the Fried noodles and how they taste like and how the fried noodles are invented. So the content of the target text cannot be expected to conform wholly to the source text and some points should be slightly adjusted. Sentences 2-6 which tell readers the invention story and the cooking procedure should therefore be translated without missing out a tiny part the information while the first sentence functioning as an introduction of the historical figure 伊秉绶 (Yi Bingshou, governor of Huizhou) can be more precise in the target text.

Moreover, in the source text, some sentences are structured with the subject shifting from one clause to another so that the sentences seem chockablock with the disordered information (See Sentences 1, 2 and 5). To comply with the English language grammar rule that a sentence contain one subject only and it is a consistent whole dominating the whole sentence by referring to the other subjects, if any, of the clauses of the sentence in the co-ordinate or subordinate order, the translator should put all the clauses in the hierarchy where they each kept in its position start with their own subjects that relate to one another and to the subject of the sentence in the required order. Briefly, the translator can either make them several sentences or apply the compound and complex English sentence structure when handling them in translation. In the following are some specific ways to assess the quality of the translation and to improve the work:

Sentence 1 in the source text introduces the historical figure, Yi Bingshou, governor of Huizhou's title and personality which should not be the focus of the whole text when translated into English. So the translator should have put it in a short and precise way by deleting unnecessary the information such as "of the Manchurian ethnic minority". 
And in the clauses “为官清廉, 从不趋炎附势”, the second one “从不趋炎附势”is a further explanation of “为官清廉”. In translation, "be honest and upright" will do because it covers the meaning of "never curried favor with the rich and powerful", a part of the sentence proved redundant. Therefore, to better translate Sentence 1 in the source text, the target text should delete "of the Manchurian ethnic minority" and "never curried favor with the rich and powerful" and combine Sentences 1, 2 and 3 into a compound sentence.

Sentences 2-9 in the source text which tell readers the invention story of the fried noodles and the cooking procedure and how they overspread should have been translated with no tiny part of the information missed out. But this target text misses two important points: one is why noodles are served at the birthday party which is told in Sentences 3 and 4 of the source text and the other is the fact that the fried noodles have been introduced to every household which is mentioned in the last sentence of the source text.

Based on the analysis above, a revised version of target text is provided:

As governor of Huizhou in the days of the Qing dynasty, Yin Bingshou, was so honest and upright that local gentry were afraid of him. On his birthday, wealthy people gave him an enormous amount of noodles as a birthday gift since they knew he loved noodles. The governor then and there decided to serve noodles to the well-wishers. Disrupted from their routine birthday preparation, the cooks mistakenly put the noodles into pots filled with oil for deep-frying, instead of putting them in pots with water. The guests admired the fried noodles for being "tasty". Delighted, the magistrate asked the guests to take home any fried noodles they could not finish. On this basis, developed the recipe for fried noodles, or so it is said.

\section{B. The Summary of Common Translation Problems}

The problems existing in the English translation of Chinese food culture text can be summarized into language, structure and function. At the linguistic level, words for beautifying the language, enhancing the atmosphere in the source text are translated in English only by replacing them with certain "equivalent" or "synonymous" in English and some subject-shifting sentence structures in source text are simply translated into several simple English sentences, failing to adopt typical English compound sentence structure with inserted elements and post-modifiers. As for the structural problems, the loose textual structure of source text devotes most to the introduction to historical stories about the cuisine which are mistakenly saved in the target text without omitting any tiny information. Finally, the English translation of Chinese food culture text is done without clear translation function in advance. Consequently it often ignores the importance of adapting source text to English thinking pattern and the features of western food culture text.

\section{The Translation Strategy of C-E Translation of Chinese Food Culture Text}

The assessment is from beginning to end coupled with the author proposing some translation strategies based on the functionalist approaches which are shown in the following:

A functionalist translation process should start at the pragmatic level by deciding on the intended function of the translation. As the function, intention or the purpose is determined, all the other things have to be made to align with it. Furthermore, such process entails the target reader orientation, that is, the translation must be adapted to the receivers' background knowledge, expectations and communicative needs.

Accordingly, when handling the content and composition part, the translator is advised to do away with the part devoted to detailing the unimportant person or place's name and irrelevant detailed information in contents of introduction to the long historical stories about the cuisine. But for famous figures and their titles, supplement explanatory clauses are needed so as to achieve the communication function.

At the sentence level, the translator may use the simple sentence construction, aided by various language elements such as words or phrases as post-modifiers, words or phrases as inserted elements and words or phrases as the adverbial of cause, manner, time and etc and, in a few cases, complex sentences.

At the lexis level, the translator has to make sure that the essential information is kept in the process, to neutralize the cultural connotations of some cultural words and the exaggerative effects those words for enhancing atmosphere and/or beautifying language might produce, simply by using plain language to convey the meanings and by shortening the words or phrases.

\section{CONCLUSION}

As has been demonstrated throughout the study, translation is the production of a functional target text maintaining a relationship with a given source text that is specified as an offer of information in a new situation according to the translation purpose. It is the specification of the function of the source text or its elements of content or structure that permits the translator to decide whether or not these elements are an appropriate means of performing the intended function of the target text. Therefore, the source text shouldn't be translated word by word but only translation-oriented elements of it should be picked out from the excessive information in Chinese food culture text and translated into English text, considering the translation function of promoting Chinese cuisine, English thinking pattern and the features of Western food culture text. The English translation of Chinese food culture text should adjust the source text in some way, such as omit the words for beautifying language and redundant modifying, summarize the long historical 
stories and delete the unimportant person or place's name, supplement explanatory clauses for famous figures and his title, reconstruct textual structures where it is necessary.

\section{ApPendix A Chinese FoOd Culture TeXt SAMPLES}

The sentences indicating physical feature of the Chinese and western food culture text are underlying with ' $\approx \approx$ ' while the sentences indicating anecdotes are underlying with “ . And each sentence is marked with alphabet.

(1). a. 北京烤鸭是首屈一指的中国名菜佳馔，已有三百多年的历史。b. 如果单单追溯烤鸭的起源，那就更早 了。c. 宋、元两朝, 已有关于多鸭、烧鸭 (均为烤鸭) 的文字记载。d. 公元一三六八年, 明太祖朱元璋建都 南京, 宫廷御厨采用炭火烘烤, 烹制南京湖鸭, 使鸭子酥香肥美, 肥而不淢, 被皇府取名为“烤鸭”。e. 朱元璋 死后, 燕王朱棣称帝, 并迁都北京, 烤鸭技术也随之带到北京, 并得到进一步发展。f.到了清朝, 烤鸭成为乾隆 皇帝、慈禧太后以及王公大臣们所喜爱的宫廷菜，正式命名为“北京烤鸭”。

Beijing roast duck is second to none among Chinese traditional delicious food with a 300-year-long history. Dating back to the original of Beijing roast duck, its history would be earlier. In Song Dynasty and Yuan Dynasty, the written records about some kinds of roast duck had appeared. In 1368, Zhu Yuanzhang, the first emperor of Ming Dynasty, set up his capital in Nanjing, where the royal chef used coal to roast Nanjing lake ducks soft, fragrant, fleshy, delicious, but not greasy, so that they were called "roast ducks" by the royal palace. After the death of Zhu Yuanzhang, his fourth son, Prince Yan, Zhu Di became the king and then moved the capital to Beijing. So the technology of roasting ducks was brought to Beijing and developed further. In Qing Dynasty, roast ducks became the royal dish favored by King Qian Long, Queen Mother Ci Xi and other royal families and officials. So finally this dish was officially named as "Beijing Roast Duck".

Guide to China-Delicious Foods (Cui Zhiyu, Xu Beili, 2002:)

(2). a. 涮羊肉, 又称羊肉火锅, 是北京传统名菜, 它颇具食趣, 食者自己动手, 边浰、边蘸调料食用, 热梁 鲜美。b. 涮羊肉起源于元代。当年元世祖忽必烈率军南下, 一日, 敌军逼近, 伙夫来不及烧饭, 只能把已 切成薄片的羊肉在沸水里一惣, 再拌些调料。c. 将士们吃得津津有味, 忽必烈喜开颜笑, 便把这道菜叫作“涮 羊肉” d. 十七世纪中叶涮羊肉传入北京。e. 嘉庆年间，宫廷曾大设“千叟宴”，用火锅一千五百个。f. 丛此， “羊肉火锅”之名大震。而“涮羊肉”逐渐走向民间则是在清光绪年间。

Instantly Boiled Mutton in a Mongolian Fire Pot is a famous traditional cuisine in Beijing. It also can be called Mutton in Fire pot. It is really fun in eating, you can DIY-boiling the mutton while dressing the seasoning and eat. It is heat and delicious.Instantly Boiled Mutton in a Mongolian Fire Pot resourced from Yuan Dynasty. At that time, the first king, Hubilie led his army down northward. One day, because of the force of enemy, the chefs of Yuan's army had no time to cook. They only put sliced mutton into boiled water and dressed some seasons. However, generals and soldiers enjoyed it very much. Kublai Khan was excited so he named the cuisine "Instantly Boiled Mutton in a Mongolian Fire Pot".In the middle of 17th century, the boiled mutton was brought in Beijing. In the year of Jia Qing, a feast called "thousand men feast" was taken place in the Palace, which used 1,500 fire pots. From now on, "Mutton in Fire Pot" became famous and the public accepted boiled mutton. Overall, in the period of King Guang Xu, Qing Dynasty, Instantly Boiled Mutton in a Mongolian Fire Pot became popular.

Guide to China-Delicious Foods (Cui Zhiyu, Xu Beili, 2002:8)

（3）ａ．洪武豆腐系安徽凤阳传统名菜，已有六百多年历史。b. 明朝开国皇帝朱元璋年幼时，因家境贫苦，靠 气讨度日。c. 凤阳城内一家小饭馆的老板可怜他, 就经常送一些酿豆腐给他食用。d. 朱元璋当上皇帝后, 时常 想起具有家乡风味的酿豆腐, 便把饭店的老板和㕑师召入皇宫, 为他专门制作此菜, 称为“洪武豆腐”, 驰名于 世。

Bean curd has been a famous dish for more than 600 years in Fengyang, Anhui Province. When he was young and long before he became emperor, Zhu Yuanzhang lived by begging. A small restaurant owner in Fengyang took pity on the boy and often gave him some bean curd for food. After Zhu became the founding emperor of the Ming Dynasty, with the reign title of Hongwu, he missed the bean curd from his own town that he had eaten during his childhood. So he had the owner and cook of the small restaurant brought to the palace to cook this dish for him. Since then it has been known as Emperor Hongwu's Bean Curd.

Chinese Cuisine Recipes and Their Stories (Zhang Enlai.2001:128)

\section{APPEndix B: WeStern FoOd Culture TeXT SAMPLES}

(4). a. Paella is currently an internationally-known rice dish from Spain. b.It originated in the fields of a region called Valencia in eastern Spain. c. Today paella is made in every region of Spain, using just about any kind of ingredient that goes well with rice. $d$. There are as many versions of paella as there are cooks. e. It may contain chicken, pork, shellfish, fish, eel, squid, beans, peas, artichokes or peppers. f. Saffron, the spice that also turns the rice a wonderful golden color, is an essential part of the dish. g. There is an old story of how the Moorish kings' servants created rice dishes by mixing the left-overs from royal banquets in large pots to take home. h.It is said by some that that word paella originates from the Arab word "baqiyah" meaning left-overs. i. However, linguists believe that the word paella comes from the name of 
the pan. j.It is made in - the Latin term patella, a flat plate on which offerings were made to the Gods. k.The stories of servants creating dishes from the King's left-overs are romantic, but we know for certain that it was not until the mid-nineteenth century that modern paella was created in an area around Albufera (a bay south of Valencia). 1.At lunch time, workers in the fields would make the rice dish in a flat pan over a fire. $\mathrm{m}$. They mixed in whatever they could find - such as snails and vegetables. $n$. For special occasions, rabbit and later chicken were added.

Source: http://spanishfood.about.com/od/maincourses/a/paella.htm

(5) a. Guacamole is a Mexican dip made of mashed avocados. b. It is flavored with chilies and lime or lemon juice, and often has chopped tomatoes, spring onion and cilantro (coriander). c. The word "guacamole" comes from two Aztec words-"agucate" meaning "avocado", and "mole" meaning "mixture". d. Some Mexican cities have their own way of serving Guacamole. e. In Monterrey, the tomatoes and onions are served as a garnish, so that the dish looks like the red, white, and green stripes on the Mexican flag.

Source: The Kids' Cookbook-- Recipes from Around the World (pp.14)

(6) a.The dish, Tripas à moda do Porto, after which the Porto people are named has a long story. b. Although there are several tripe recipes -- such as the Caen's, Lyonnaises, or the callos à Madrilenã -- none of them has such an historical framing. c. The most popular version of the legend/story -- the one that has more supporters and historical evidence -has its origin in the great adventure of the Discoveries. d. Porto-born Prince Henry needed meat to supply the caravels leaving to conquer Ceuta and asked his people to help him victual the vessels. e. The Porto people came forward and immediately filled the wooden barrels with salted meat, keeping only the tripe, which was then cooked in a thick stew with sausages and fat meat, and eaten with big slices of dark bread. f. Later on, the same man who had been responsible for the provision of the caravels, discovered new worlds, thus introducing a new ingredient - the butter bean. g. The dish became part of the history of a city, which is characterized not only by this juicy recipe -- with the flavor of cumin and black pepper, seasoned with homemade sausages and fat chicken -- but also by an altruistic gesture in a decisive moment of the Portuguese nation.

Source: http://www.a2zlanguages.com/Portugal/Porto/porto_food.htm

\section{REFERENCES}

[1] Cui Zhiyu, Xu Beili. (2002). Guide to china- delicious foods. Shanghai: Shanghai Guji Press.

[2] Hu Zhuanglin. (1994). Text cohesion and coherence. Shanghai: Shanghai Foreign Language Education Press.

[3] Liu Miqing. (2001). Translation and language philosophy. Beijing: China Translation and Publishing Corporation.

[4] Nord.C. (2006). Text analysis in translation: Theory, methodology, and didactic application of a model for translation-oriented text analysis $\left(2^{\text {nd }}\right.$ edn.). Beijing: Foreign Language Teaching and Research Press.

[5] Nord, C. (2001). Translating as a purposfu1 activity: Functionalists approaches explained. Shanghai: Shanghai Foreign Language Education Press.

[6] Rosalba Gioffre, Frances Lee. (2004). The kids' cookbook-- recipes from around the world. Florence: Mc Rae Books Srl.

[7] Zhang Enlai. (2001). Chinese cuisine recipes and their Stories. Beijing: Foreign Languages Press.

[8] A2Z Languages (International Language Immersion Programs) (no date). Great Tasting Portuguese Dishes and Recipes. http://www.a2zlanguages.com/Portugal/Porto/porto_food.htm (accessed 2/10/2012)

[9] Lisa \& Tony Sierra (no date). Paella- An Introduction to Spanish paella http://spanishfood.about.com/od/aincourses/a/paella.htm(accessed 2/10/2012)

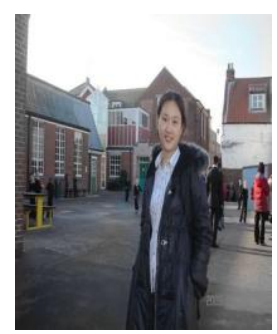

Siwei Yue was born in Hubei Province, China, in 1984. She received her B.A in 2006, M.A in Foreign Linguistics and Applied Linguistics in 2008 both from Guangdong University of Foreign Studies. She's currently working in Foreign Languages Department, Guangdong University of Education. Her research interests include business English studies, intercultural business communication. 